\title{
Psykologer må få henvisningsrett
}

\author{
Dagens ordning der pasienter som har vært til vurdering hos psykolog, alltid må tilbake til fastlegen for å bli \\ henvist videre, er svært kostnadsdrivende. Den er også tungvinn for fastlegene og pasientene. Psykologer må \\ gis rett til å henvise videre de pasienter som trenger det.
}

Jobber man som psykolog på et kontor for pedagogisk-psykologisk tjeneste (PPTkontor) eller i kommunehelsetjenesten og trenger hjelp fra en barne- og ungdomspsykiatrisk klinikk (BUP-klinikk) til å gjøre en vurdering av et barn eller en ungdom, er henvisningsrett nødvendig.

Noen eksempler: En psykolog har fătt en henvendelse fra fastlege, skole eller bekymret helsesøster om et barn eller en ungdom. Etter
Et annet eksempel er suicidale pasienter. Jeg har erfaring med slike pasienter fra min tid som psykolog i spesialisthelsetjenesten. Når jeg som kommunepsykolog får inn en pasient med selvmordstanker og tydelige depressive symptomer, kan jeg vurdere om det er overhengende fare for suicid. I motsetning til fastlegen har jeg imidlertid ikke hjemmel i lovverket for å begjære vedkommende innlagt på egnet institusjon. I slike

\section{«Fastlegeordningen må kunne sies å være en suksess. Likevel kan ordningen av og til virke som en flaskehals»}

en eller flere konsultasjoner vurderer psykologen det slik at det trengs en videre utredning for å finne ut hvilken psykisk lidelse vedkommende kan lide av. Det kan være mistanke om incest, annen form for misbruk eller ulike psykiske forstyrrelser, slik som $\mathrm{AD} / \mathrm{HD}$, Aspergers syndrom, autisme eller Tourettes syndrom. Likevel må psykologen, slik systemet er nå, henvise tilbake til fastlegen og nærmest diktere hva fastlegen skal skrive i sin henvisning. Som en erfaren psykolog en gang fortalte meg: Jeg har aldri opplevd at en fastlege har motsatt seg mine anbefalinger. I stedet for å henvise pasienten direkte til en spesialist i for eksempel nevropsykologi eller nevrologi, må saken innom fastlegen. tilfeller må psykologen, som har både utdanning og erfaring med denne type problematikk, henvende seg til fastlegen med sine anbefalinger. Det samme gjelder for psykotiske pasienter, som kan være til fare for seg selv og for andre og trenger umiddelbar innleggelse på døgnavdeling. Psykologer har både kunnskap om slike lidelser og erfaring med å møte slike mennesker; likevel er det fastlegen som skal henvise disse pasientene videre.

Det er ingen tvil om at fastlegesystemet har ført til en forbedring på mange områder. Fastlegeordningen må kunne sies å være en suksess. Likevel kan ordningen av og til virke som en flaskehals. I mange tilfeller er det psykologer som sitter med den faglige tyngden i førstelinjetjenesten, mens det er fastlegen som sitter med henvisningsretten.

Jeg har snakket med mange leger som gjerne skulle ha sett at psykologen både kunne henvise og sykmelde, fordi det gir legene mer tid til direkte pasientarbeid. Jeg tror Legeforeningens proteksjonistiske politikk har vært en vesentlig bidragsyter til dagens system. I noen tilfeller er det opplagt at andre yrkesgrupper enn leger bør kunne henvise videre - på enkelte områder har man endret dette: Kiropraktorer kan henvise til MR-undersøkelse av ryggen, og optikere kan henvise til øyespesialister. Jeg tror ingen synes dette er galt. Også psykologer må få rett til å henvise videre.

\section{Olav Kandal \\ kandal.olav@gmail.com \\ $\mathrm{Bø}$}

Olav Kandal (f. 1968) arbeider som psykolog i kommunehelsetjenesten og i PP-tjenesten. Han har tidligere jobbet i spesialisthelsetjenesten. Han er også frilansjournalist. Ingen oppgitte interessekonflikter.

Mottatt 25.3. 2011, første revisjon innsendt 16.4 2011, godkjent 28.4. 2011. Medisinsk redaktør Petter Gjersvik. 